\title{
Kidney injury associated with COVID-19
}

\author{
Daniel Blum MDCM, Alejandro Meraz-Munoz MD, Ziv Harel MD MSc
}

Cite as: CMAJ 2020 September 14;192:E1065. doi: 10.1503/cmaj.201553

1 As many as $40 \%$ of patients admitted to hospital with COVID-19 have acute kidney injury

Acute kidney injury (AKI) is a common complication of coronavirus disease 2019 (COVID-19) and is usually related to disease severity. Accordingly, it typically occurs in patients who are critically ill, those with pre-existing conditions, older adults and Black people. ${ }^{1}$

\section{Patients commonly present with dipstick-positive hematuria and mild proteinuria ${ }^{1}$}

Uncommon presentations for AKI include nephrotic range proteinuria reflecting glomerular damage and new-onset glucosuria as a result of proximal tubular damage. ${ }^{2}$ Referral to a nephrologist should be sought for patients with severe COVID-19 who have a greater than 50\% increase in their creatinine level compared with baseline, those with urinary protein excretion of more than $1 \mathrm{~g} / \mathrm{d}$ and for those with a history of chronic kidney disease (estimated glomerular filtration rate $<60$ ).

\section{3}

Hemodynamic insults, immunologic injury, hypercoagulability and microangiopathy drive kidney injury associated with COVID-193

There is no strong evidence that severe acute respiratory syndrome coronavirus 2 (SARS-CoV-2) has direct cytotoxic effects on the kidney despite the abundant expression of angiotensin-converting enzyme 2 (ACE2) in the kidney, which is used by SARS-CoV-2 to enter host tissue. ${ }^{2}$

Patients on long-term treatment with ACE inhibitors and angiotensin receptor blockers are not at increased risk of COVID-19

Use of ACE inhibitors and angiotensin receptor blockers does not impart a higher risk of COVID-192 or having poor outcomes from the disease, including critical illness and death. ${ }^{4}$ They should not routinely be stopped in patients with or at risk of COVID-19, unless there are medical indications to do so, such as hyperkalemia or AKI.

Patients receiving dialysis often present atypically with COVID-19 In contrast to the general population, patients receiving renal replacement therapy often present without fever or respiratory symptoms but with fatigue, anorexia and lymphopenia. ${ }^{5} \mathrm{~A}$ high index of suspicion because of the range of presentations of COVID-19, the use of universal droplet precautions when caring for patients and a low threshold for testing for SARS-CoV-2 are suggested when managing this population.

\section{References}

1. Hirsch JS, Ng JH, Ross DW, et al. Acute kidney injury in patients hospitalized with COVID-19. Kidney Int 2020;98: 209-18.

2. Kudose S, Batal I, Santoriello D, et al. Kidney biopsy findings in patients with COVID-19. J Am Soc Nephrol 2020 July 17; ASN.2020060802. [Epub ahead of print]. doi: 10.1681/ASN .2020060802 .

3. Ronco C, Reis T. Kidney involvement in COVID-19 and rationale for extracorporeal therapies. Nat Rev Nephrol 2020;16:308-10.

4. Mancia G, Rea F, Ludergnani M, et al. Renin-angiotensinaldosterone system blockers and the risk of COVID-19. N Engl J Med 2020;382:2431-40.

5. Wu J, Li J, Zhu G, et al. Clinical features of maintenance hemodialysis patients with 2019 novel coronavirus-infected pneumonia in Wuhan, China. Clin J Am Soc Nephrol 2020;15: 1139-45.

Competing interests: None declared.

This article has been peer reviewed.

Affiliations: Division of Nephrology (Blum), Jewish General Hospital, Montréal, Que.; Division of Nephrology (Meraz-Munoz, Harel) St. Michael's Hospital, Toronto, Ont.

Acknowledgments: The authors thank Dr. Ron Wald and Dr. Martin Schreiber for their critique and helpful suggestions in the preparation of this manuscript.

Correspondence to: Ziv Harel, ziv.harel@ unityhealth.to

CMAJ invites submissions to "Five things to know about ..." Submit manuscripts online at http://mc. manuscriptcentral.com/cmaj 